Acta vet. scand. $1967,8,150-156$.

From the Department of Medicine, Veterinary College of Norway, Oslo.

\title{
SERUM TRANSFERRINS OF NORWEGIAN RED CATTLE
}

\author{
By \\ Mikael Brænd and Narendra Dass Khanna*)
}

Cattle serum transferrins (Tf) or beta-globulins as they were first called have been extensively studied since the reports by Ashton (1957) and Smithies \& Hickman (1958). In the original studies a number of different Tf phenotypes diagnozed by the technique of starch gel electrophoresis were reported. They were explained by the action of three allelic genes, called $\mathrm{Tf}^{\mathrm{A}}$, TfD and Tf ${ }^{E}$. Improved techniques based upon Poulik's (1957) discontinuous buffer system made further distinctions possible between Tf phenotypes (Kristjansson 1962). The Tf bands previously assigned to the action of one allele, $\mathrm{Tf}^{\mathrm{D}}$ were subdivided and explained by two genes. These were called $\mathrm{Tf}^{\mathrm{d}_{1}}$ and $\mathrm{Tf}^{\mathrm{d}_{2}}$ by Jamieson (1965) who found them to be of relatively high frequencies in British cattle breeds. Additional $T f$ alleles, $\mathrm{Tf}^{\mathrm{B}}$ and $\mathrm{Tf}^{\mathrm{F}}$ were reported by Ashton (1959) and the allele TfG by Osterhoff $\&$ van Heerden (1965). The TfG symbol was used by Ashton $\&$ Lampkin (1965) for still another allele. Jamieson suggested the symbol $\mathrm{Tf}^{\mathrm{a}_{1}}$ for this. An allele called $\mathrm{Tf}^{\mathrm{H}}$ was reported by Sartore \& Bernoco (1966).

The most important cattle breed in Norway is Norwegian Red Cattle (NRF), a breed which has been developed during the last 30 years. It is based on Ayrshire and cattle derived from Ayrshire, but is also considerably influenced from Dairy Shorthorn. Nor-

*) On leave from Indian Veterinary Research Institute, Izatnagar, U.P., India, with a scholarship from Norwegian Agency for International Development. 
wegian Red Polls which previously was a separate breed has also contributed in building NRF.

The purpose of the investigations of which the results are given in the present report was to study rare $\mathrm{Tf}$ phenotypes, inheritance and distribution of Tf alleles in NRF.

\section{MATERIALS AND METHODS}

A total of 535 animals were examined for the purpose of $\mathrm{Tf}$ frequency studies. The majority of samples, 371, came from 2 to 6 months old bull calves in progeny groups. They were offspring from 54 A.I. bulls. Samples from the dams were not available. Twenty-nine of the bulls had from 8 to 11 offspring, the rest from 1 to 18 . The samples were collected over a 6 years' period. They were bled into plastic tubes containing heparin or sodium citrate, treated in the usual way and stored below $-20^{\circ} \mathrm{C}$. The rest of the samples for frequency studies, 164, came from dams. Blood samples from these and their offspring were sent to our laboratory by practising veterinarians for confirmation of parentage. These samples were also collected over a 6 years' period.

In addition a small bull family consisting of the bull, 5 dams and their offspring were investigated for the purpose of studying the inheritance of a rare $\mathrm{Tf}$ allele.

The technique for determination of Tf phenotypes was starch gel electrophoresis. Poulik's (1957) discontinuous horizontal buffer system was employed but modified to obtain separation of the $D_{1}$ and $D_{2}$ bands. (In the present report we are going to use capital letters for $\mathrm{Tf}$ alleles and $\mathrm{Tf}$ phenotypes, accordingly $\mathrm{Tf}^{\mathrm{A}}$, $\mathrm{Tf}^{\mathrm{D}_{1}}$ and so on). Gels of dimension $22 \times 13 \times 0.5 \mathrm{~cm}$ were prepared from 0.02 $\mathrm{M}$ tris (Sigma 7-9) and $0.006 \mathrm{M}$ citric acid, $\mathrm{pH}$ 7.6. Commercial Norwegian potato starch was hydrolysed at $37^{\circ} \mathrm{C}$ for 75 min. and used at a concentration of $10 \%$. Insertions were made on filterpaper $3 \mathrm{~cm}$ from the cathodic bridge. Starting voltage was $165 \mathrm{v}$ across the gel giving 4 mamp. per cm. After $1 / 2 \mathrm{hr}$. increase was made to $350 \mathrm{v}$ and 4.5 mamp. The gel was covered with a thin polyethylene sheet. Electrophoresis was stopped when the borate line had moved $10 \mathrm{~cm}$ beyond the insertion line. No cooling was applied even though the gel got very hot during the run. Staining and destaining was done according 


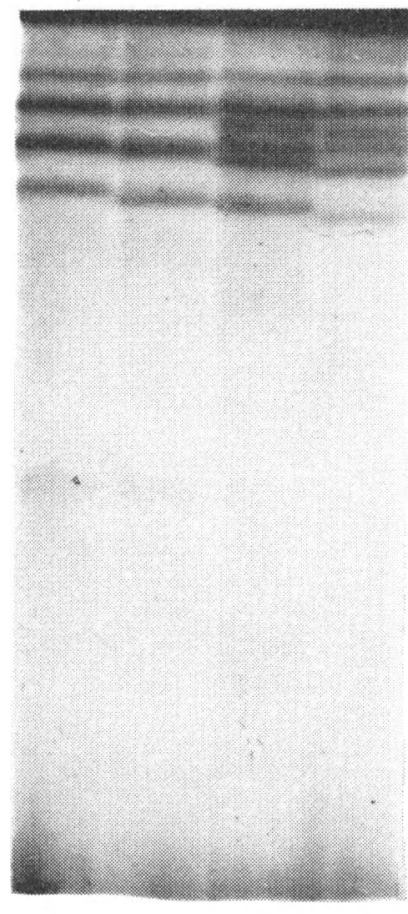

$\mathrm{AD}_{1} \quad \mathrm{AD}_{2} \quad \mathrm{AF} \quad \mathrm{AN}$
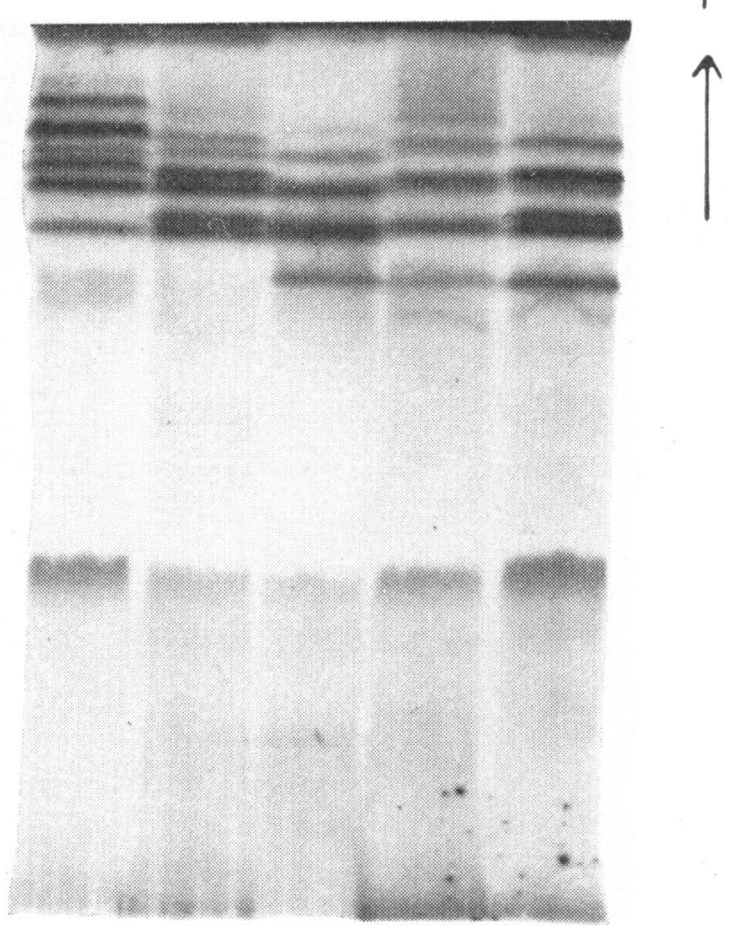

$\begin{array}{lllll}\text { AN } & \mathrm{D}_{2} \mathrm{~N} & \mathrm{NE} & \mathrm{D}_{2} \mathrm{E} & \mathrm{D}_{1} \mathrm{E}\end{array}$

F i g. 1. Photograph of two starch gels where phenotypes heterozygous for $T f^{N}$ are compared with selected Tf cattle phenotypes.

to Smithies (1955) after the gel had been sliced in the middle by the use of the thinnest available nylon fishing line.

For statistical analyses conventional methods were employed.

\section{RESULTS}

Altogether 13 different Tf phenotypes were observed. Ten of them correspond to those described in detail by Jamieson (1965). The 3 additional phenotypes are shown in Fig. 1. These 3 phenotypes ( $\mathrm{AN}, \mathrm{D}_{2} \mathrm{~N}$ and $\mathrm{NE}$ ) all have certain $\mathrm{Tf}$ bands matching each other which have not been described previously, except for those of the AN phenotype which was first reported by Gahne (1961), by him called a new type. This band pattern which is named $N$ (after Norway) appears as 3 or 4 bands with the technique used in the present studies. The appearance of the fourth band was found to be variable because of its faintness. The $\mathrm{N}$ bands migrate 
T a ble 1. Observed and expected distributions of Tf phenotypes and Tf gene frequencies.

\begin{tabular}{lllllclll} 
& $\mathrm{AA}$ & $\mathrm{AD}_{1}$ & $\mathrm{AD}_{2}$ & $\mathrm{AN}$ & $\mathrm{AE}$ & $\mathrm{D}_{1} \mathrm{D}_{1}$ & $\mathrm{D}_{1} \mathrm{D}_{2}$ & $\mathrm{D}_{1} \mathrm{~N}$ \\
\hline Obs. & 60 & 69 & 90 & 3 & 98 & 16 & 29 & - \\
Exp. & 67.46 & 60.38 & 82.37 & 1.41 & 100.84 & 13.51 & 36.86 & 0.63
\end{tabular}

\begin{tabular}{lllllllll} 
& $\mathrm{D}_{1} \mathrm{E}$ & $\mathrm{D}_{2} \mathrm{D}_{2}$ & $\mathrm{D}_{2} \mathrm{~N}$ & $\mathrm{D}_{2} \mathrm{E}$ & $\mathrm{NN}$ & $\mathrm{NE}$ & $\mathrm{EE}$ & Total \\
\hline Obs. & 40 & 24 & 1 & 64 & - & - & 41 & 535 \\
Exp. & 45.12 & 25.15 & 0.86 & 61.57 & 0.01 & 1.05 & 37.68 & 534.90
\end{tabular}

$$
\begin{aligned}
& \text { Gene frequencies: } \mathrm{TfA}=0.3551, \quad \mathrm{TfN}=0.0037 \text {, } \\
& \mathrm{TfD}_{1}=0.1589, \quad \mathrm{TfE}=0.2654 \\
& \mathrm{TfD}_{2}=0.2168 \text {, } \\
& \chi^{2}=6.00 ; 0.5>\mathrm{P}>0.3 \quad, 6 \text { d.f. }
\end{aligned}
$$

slightly slower than the $\mathrm{D}_{2}$ bands, but so that the respective bands of the $\mathrm{D}_{2}$ and $\mathrm{N}$ patterns are clearly separated. Accordingly the phenotype $D_{2} \mathrm{~N}$ appears as a 6 band pattern with 2 very faint bands (not seen on the photograph) in front. The AN phenotype also shows 6 major bands. The phenotype NE appears as a 5 band pattern due to overlapping of bands. It is very similar to the $D_{2} E$ phenotype, but our technique allows a clear distinction between these 2. For comparison a $D_{1} E$ phenotype is also shown in Fig. 1.

After the description given by Ashton (1959) for Tf phenotypes heterozygous for $\mathrm{Tf}^{\mathrm{F}}$ it was impossible to determine whether the allele involved in the control of the Tf $N$ phenotypes was different from $\mathbf{T f}^{\mathrm{F}}$. A reference sample $A F^{\star}$ ) was therefore compared with $A N$. The results are shown in Fig. 1. It appears that the Tf AF and Tf AN phenotypes are different, the Tf $N$ bands with slightly slower rate of migration than the Tf $F$ bands in our gels. For comparison Tf phenotypes $A_{1}$ and $A D_{2}$ were run in the same gel.

The appearance of the $\mathrm{N}$ bands justified a genetic theory of a codominant allele $\mathrm{Tf}^{\mathrm{N}}$ being in control of the $\mathrm{N}$ protein bands.

The Tf phenotyping of the members of the bull family showed that the TfN allele of the bull had been transmitted to 3 out of the 5 offspring. Two of them were $\mathrm{NE}$ and $1 \mathrm{D}_{2} \mathrm{~N}$. The dams were all negative for $\mathrm{Tf}^{\mathrm{N}}$.

Results from frequency studies are given in Table 1. The

*) Kindly provided by Dr. G. C. Ashton. 
number of observed Tf phenotypes agrees with that expected. According to the genetic theory 2 additional Tf phenotypes are expected to occur. Due to the low frequency of $\mathbf{T f}^{\mathrm{N}}$ it is, however, not surprising that $\mathrm{Tf}$ NN was not found. The lack of phenotype $\operatorname{TfD}_{1} \mathrm{~N}$ in our material we consider a mere matter of chance.

Summarizing, we find it justified to conclude the correctness of the genetic theory and that the $\mathrm{Tf}^{\mathrm{N}}$ allele is still another allelomorph of the Tf system in cattle.

\section{DISCUSSION}

Transferrin shows different molecular forms within riost animal species. The number and frequencies of the various forms differ from species to species. In some species one form is far the most common. This is the case with the human transferrins in European Whites. Accordingly the other and rare forms are often called variants. When such a situation exists for the Tf system of a population the polymorphism can hardly be considered as a genetic polymorphism according to Ford (1945). In many populations of our domestic animals, however, the Tf system has relative allele frequencies which conform to the designation genetic polymorphism, which means that the Tf alleles influence or has influenced fitness in some way or other.

This is the case in many cattle populations. In the NRF breed $4 \mathrm{Tf}$ alleles occurred at frequencies above 0.1 , which may be used as an arbitrarily chosen limit between polymorphic and non polymorphic genes. Such a limit must, however, primarily be considered as a matter for discussion. There may be genes of frequencies below 0.1 which make a true genetic polymorphism. In this connection we must realize the strong selective forces which may act in populations of domestic animals in contrast, for instance, to human populations and populations of wild animals. In populations with strong artificial selection eventual genetic polymorphism may be masked. On the other hand genes of high frequencies may not be polymorphic in a certain population even though they might have been sometimes in the past. The nature of the Tf polymorphism in cattle has been subject to speculations, theories and investigations. It is, however, probably right to say that we still do not know much about the effects of cattle Tf alleles on fitness. We may be in a better situation to 
judge, when we know the exact chemical structure of the various Tf polypeptide chains.

The very rare allele $\mathrm{Tf}^{\mathrm{N}}$ has so far only been found in Norwegian cattle and only in animals of Red Poll origin. No systematic study of Tf distributions within populations of Red Polls has, however, been carried out. But as long as the $\mathrm{Tf}^{\mathrm{N}}$ allele was recognized in several animals not included in the present material (Brænd unpublished), it probably occurred more commonly previously, although still at a frequency considerably below 0.1 . In the future this allele probably will continue to be of a very low frequency. Actually, because of the breeding policy and because it is so rare, the chances that $\mathrm{Tf}^{\mathrm{N}}$ shall be extinct are rather great.

Whether the $\mathrm{Tf}^{\mathrm{N}}$ allele is an old or a young allele is another matter for discussion. However, as long as this allele is easy to recognize especially in the phenotypes $A N$ and $D_{2} N$, and as long as it has not been detected in any other breed so far, including Icelandic cattle, it is in our opinion most reasonable to assume that it is a relatively new allele.

\section{REFERENCES}

Ashton, G. C.: Serum protein differences in cattle by starch gel electrophoresis. Nature (Lond.) 1957, 180, 917-919.

Ashton, G. C.: $\beta$-globulin alleles in some Zebu cattle. Nature (Lond.) 1959, 184, 1135-1136.

Ashton, G. C. \& G. H. Lampkin: Serum albumin and transferrin polymorphism in East African cattle. Nature (Lond.) 1965, 205, $209-210$.

Ford, E. B.: Polymorphism. Biol. Rev. 1945, 20, 73-88.

Gahne, B.: Studies of transferrins in serum and milk of Swedish cattle. Animal. Prod. 1961, 3, 135-145.

Jamieson, A.: The genetics of transferrins in cattle. Heredity 1965, 20, $419-441$.

Kristjansson, $F$. K.: Recent research in serum protein polymorphism of livestock. 8th Europ. Animal Blood Group Conf. 1962 (mimeo).

Osterhoff, D. R. \& J. A. H. van Heerden: TfG - a new transferrin allele in cattle. Proc. 9th Europ. Animal Blood Group Conf. 1965, $311-312$.

Poulik, M. D.: Starch gel electrophoresis in a discontinuous system of buffers. Nature (Lond.) 1957, 180, 1477-1478.

Sartore, G. \& D. Bernoco: Researches on biochemical polymorphisms in indigenous cattle of Piedmont. Proc. X Europ. Conf. Animal Blood Groups and Biochemical Polymorphism 1966. (In press). 
Smithies, O.: Zone electrophoresis in starch gels. Biochem. J. 1955, 61, $629-641$.

Smithies, O. \& C. G. Hickman: Inherited variations in the serum proteins of cattle. Genetics 1958, 43, 374-385.

\section{SUMMARY}

Starch gel electrophoresis has been used for studies on serum transferrin (Tf) polymorphism in Norwegian Red Cattle (NRF). A total of 13 different Tf phenotypes were observed. Three of them were heterozygous for the very rare allele, $\mathrm{TfN}$, which so far has not been found in any other cattle breed. The 4 protein zones controlled by $\mathrm{Tf}^{\mathrm{N}}$ are slightly slower in rate of migration than the corresponding ones governed by $\mathrm{Tf}^{\mathrm{F}}$.

The 10 other phenotypes are controlled by the alleles TfA, Tf $\mathrm{D}_{1}$, $\mathrm{Tf}^{\mathrm{D}_{2}}$ and $\mathrm{Tf} E$. In a material comprising 535 cattle these alleles occurred at frequencies $0.35,0.16,0.22$ and 0.27 respectively.

\section{ZUSAMMENFASSUNG}

Serum Transferrin bei dem norwegischen roten Vieh.

Serum Transferrin (Tf) Polymorphie ist mit Hilfe von Stärkegelelektrophorese bei dem norwegischen roten Vieh (NRF) untersucht worden. Insgesamt wurden 13 verschiedene Phänotypen nachgewiesen. Drei von diesen waren heterozygotisch in dem sehr seltenen Allel TfN, der bisher in keiner anderen Viehrasse gefunden worden ist. Die 4 Proteinzonen, die von TfN kontrolliert werden, besitzen eine etwas geringere Wanderungsgeschwindigkeit als die entsprechenden, die von $\mathbf{T f F}$ geleitet werden.

Die weiteren 10 Phänotypen werden von den Allelen $\operatorname{TfA}, \operatorname{Tf}_{1}$, $\mathrm{TfD}_{\mathbf{2}}$ und $\mathrm{TfE}$ kontrolliert. In einem Material, das aus 535 Stück Vieh bestand, traten diese Allele mit folgenden Frequenzen: 0,35, 0,16, 0,22 und 0,27 auf.

\section{SAMMENDRAG}

Serum transferrin hos Norsk rødt fe.

Serum transferrin (Tf) polymorfisme er blitt studert hos Norsk rødt fe (NRF) ved hjelp av stivelsesgelelektroforese. I alt ble det påvist 13 forskjellige fenotyper. Tre av disse var heterozygote for den meget sjeldne allel $\mathrm{Tf}^{\mathrm{N}}$ som hittil ikke er blitt funnet $\mathrm{i}$ noen annen storferase. De fire proteinsoner som kontrolleres av $\mathrm{Tf}^{\mathrm{N}}$ har en litt saktere vandringshastighet enn de tilsvarende styrt av $\mathrm{TfF}$.

De ti andre fenotyper er kontrollert av allelene $\operatorname{Tf}^{\mathrm{A}}, \operatorname{Tf}^{\mathrm{D}_{1}}, \operatorname{Tf}^{\mathrm{D}_{2}}$ og TfE. I et materiale bestående av 535 storfe forekom disse alleler med følgende frekvenser: $0,35,0,16,0,22$ og 0,27 . 